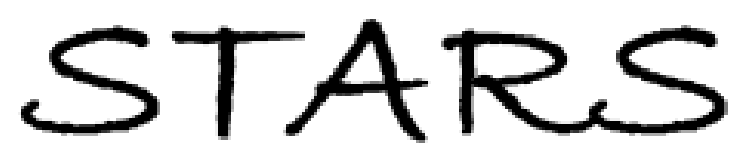

Journal of Health Occupations

Education

Volume 4 | Number 2

Article 13

1989

\title{
Mosby's Textbook for Long-Term Care Assistants
}

Pamela V. Rousseau R.N.

Find similar works at: https://stars.library.ucf.edu/jhoe

University of Central Florida Libraries http://library.ucf.edu

This Book Review is brought to you for free and open access by STARS. It has been accepted for inclusion in Journal of Health Occupations Education by an authorized editor of STARS. For more information, please contact STARS@ucf.edu.

\section{Recommended Citation}

Rousseau, Pamela V. R.N. (1989) "Mosby's Textbook for Long-Term Care Assistants," Journal of Health Occupations Education: Vol. 4 : No. 2 , Article 13.

Available at: https://stars.library.ucf.edu/jhoe/vol4/iss2/13

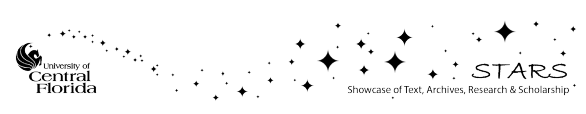




\section{Rousseau: Review: Mosby's Textbook for Long-Term Care Assistants}

Mosby's Textbook for Long-Term Care Assistants. Jean Hogan and Sheila

A. Sorrentino. The C. V. Mosby Company, St. Louis, 1988, 481 pp. Long-Term Care Assistants consists of 30 chapters designed to teach the knowledge, skills, and attitudes necessary to the nurse assistant employed in a long-term care facility. The text emphasizes the care needed by the elderly and other individuals who require long-term care. Fundamental skills of the nurse assistant, as well as the safety and psychosocial aspect of resident care, also, are stressed. Important attitudes of care, such as understanding and respecting the resident, are brought to focus.

Strengths of the text include objectives and key terms located at the beginning of each chapter. Colored pictures, many diagrams and drawings, a summary with review questions and answers at the end of each chapter, as well as a glossary are provided.

Mosby's Workbook for Long-Term Care Assistants is designed to aid in learning and reinforcement of the text. It contains both study projects and study questions for each unit. An Instructor's Manual provides suggested learning activities and test questions, and would be a valuable tool for the teacher.

Pamela V. Rousseau, R.N., Teacher, Health Occupations Education Russellville High School, Russellville, Alabama. 